\title{
PEMBUATAN APLIKASI AUGMENTED REALITY BELAJAR MENGENAL HEWAN TERNAK BERBASIS ANDROID MENGGUNAKAN UNITY PADA TK DHARMA KARTIKA
}

\author{
Anastasya Griselda Maharani Putri ${ }^{1}$, Fitri Sya'bandyah ${ }^{2}$ \\ ${ }^{1,2}$ Program Studi Teknik Informatika, Fakultas Teknik \\ Universitas Sangga Buana \\ putrigriseldaa@gmail.com ${ }^{1}$, fitri.syabandyah@usbypkp.ac.id ${ }^{2}$
}

\begin{abstract}
ABSTRAK
Pada sistem belajar anak PAUD (Pendidikan Anak Usia Dini) saat ini rata-rata masih manual. Usia anak PAUD biasanya sekitar 3-5 tahun, anak usia 3-5 tahun sangat sulit untuk dapat belajar dengan fokus ketika media yang diberikan untuk belajar yaitu buku yang masih manual, karena anak usia 3-5 tahun memiliki rasa yang cepat bosan. Untuk mengatasi masalah ini maka diperlukan metode baru untuk membuat anak tidak cepat merasakan bosan. Yaitu dengan cara menggabungkan pendidikan dengan salah satu teknologi yaitu Augmented Reality berbasis Android. Dengan metode ini anak-anak akan menjadi lebih tertarik untuk belajar. Jadi ketika anak anak bermain gadget tidak hanya bermain game non edukasi atau sekedar menonton youtube. Aplikasi yang dibuat yaitu "Augmented Reality Mengenal Hewan Ternak Berbasis Android".Hasil dari penelitian ternyata anak-anak lebih menyukai metode belajar yang menggunakan teknologi modern dibadingkan cara belajar yang manual. Maka dari itu sangat diperlukan metode belajar menggunakan teknologi agar membuat anak semakin semangat untuk belajar. Terutama anak usia dini.
\end{abstract}

Kata Kunci: Hewan ternak, Augmented Reality, Android

\section{PENDAHULUAN}

\subsection{Latar Belakang}

Pada dasarnya, teknologi diciptakan untuk memudahkan pekerjaan manusia. Saat ini teknologi telah menjadi kebutuhan utama manusia. Bahkan teknologi pun telah digunakan di semua aspek kehidupan manusia salah satunya adalah pendidikan khususnya pada kalangan Taman Kanak-kanak. Tetapi penerapan teknologi di bidang pendidikan masih sangat terbatas. Dengan demikian, jika diimplementasikan di bidang pendidikan, teknologi dapat membantu dan mempercepat tujuan pendidikan, salah satunya adalah menerapkan pembelajaran menggunakan media augmented reality pada sekolah PAUD (Pendidikan Anak Usia Dini).

Rata-rata usia anak sekolah PAUD adalah 3-5 tahun. Menurut salah satu pengajar sekolah PAUD yang pernah saya datangi mereka mengaku bahwa memang cukup kesulitan dalam mengajar anak usia dini, karena anak usia dini yang ada dalam fikirannya hanyalah bermain, dan memang sangat diperlukan hal baru untuk mengatasi anak agar anak mau menyisihkan sedikit waktu bermainnya untuk belajar. Tentunya dengan metode belajar yang baru yaitu menggunakan aplikasi augmented reality berbasis android.

Aplikasi augmented reality memang bukan hal yang baru lagi di dunia teknologi, tetapi augmented reality masih sangat jarang digunakan oleh masyarakat luas, terutama dalam bidang pendidikan belum banyak yang mengetahui aplikasi ini. Dan saya akan membuat aplikasi ini jadi dikenal masyarakat luas diluar sana. Diawali memperkenalkan ke dalam bidang pendidikan, khususnya PAUD (Pendidikan Anak Usia Dini).

Dengan menerapkan aplikasi augmented reality berbasis android ini diharapkan anak dapat tertarik dan memiliki semangat belajar yang lebih baik lagi. Dan akan diterapkan aplikasi augmented reality belajar mengenal hewan ternak berbasis android. Hewan ternak yang ada didalamnya meliputi hewan yang memiliki banyak manfaat. Salah satunya adalah domba, domba sangat banyak dikembang- 
biakan oleh orang banyak, karena memiliki manfaat yang sangat banyak. Dari mulai bulu dapat dijadikan benang hingga benang tersebut dapat dijadikan sebuah baju, lalu adapun kulitnya yang biasa dimanfaatkan untuk membuat alat musik, dan yang sudah tidak asing lagi adalah susu dan dagingnya, yang tentunya memiliki banyak manfaat yaitu kalsium dan protein.

\subsection{Rumusan Masalah}

Sesuai dengan permasalahannya, masalah dirumuskan sebagai berikut:

1. Bagaimana cara menarik perhatian anak untuk mengikuti kegiatan belajar?

2. Bagaimana meningkatkan keterampilan mengenal hewan ternak pada anak usia dini dengan media augmented reality?

3. Apakah penggunaan aplikasi augmented reality ini bisa diterapkan dalam kegiatan belajar mengajar anak usia dini?

\subsection{Manfaat dan Tujuan}

Manfaat dan Tujuan penelitian ini adalah Manfaat dari aplikasi augmented reality yang akan dirancang, sebagai berikut :

1. Dengan media pembelajaran ini diharapkan akan membantu proses pembelajaran di PAUD Dharma Kartika.

2. Akan membantu proses belajar anak.

3. Dapat meningkatkan semangat anak dalam belajar.

Adapun Tujuan pembuatan aplikasi augmented reality ini adalah sebagai berikut :

1. Untuk mengetahui sejauh mana pengetahuan anak tentang hewan ternak dan manfaat dari hewan ternak tersebut.

2. Untuk mengetahui apakah metode pembelajaran menggunakan aplikasi augmented reality ini bisa diterapkan pada anak usia dini 3-5 tahun.
3. Untuk memberikan cara alternatif sistem pengajaran yang lebih efektif dan efisien dan tentunya menarik.

\subsection{Batasan Masalah}

Adapun Batasan Masalah dari penelitian ini adalah untuk menghindari meluasnya permasalahan maka beberapa poin batasan masalah sebagai berikut :

1. Aplikasi ini hanya untuk anak usia jenjang 3 sampai 5 tahun.

2. Aplikasi ini hanya untuk belajar mengenal hewan ternak.

3. Penggunaan Media Gambar Animasi dalam meningkatkatkan pengetahuan tentang hewan ternak.

4. Program dibuat dalam format aplikasi (apk).

5. Perancangan program hanya meliputi gambar, audio dan script.

\section{LANDASAN TEORI}

\subsection{Sistem}

Suatu sistem mempunyai konsep yang mendasari sebuah pengertian-pengertian yang di kemukakan oleh para ahli dan pakar untuk mendefinisikan dari suatu sistem itu sendiri. Sebelum mendefinisikan suatu sistem para pakar harus mempunyai konsep dasar untuk memperkuat pendefinisiannya.

\subsection{Hewan Ternak}

Secara umum ternak adalah kegiatan yang dilakukan untuk sumber pangan, sumber bahan baku industri, dan dipelihara untuk membantu pekerjaan manusia seperti petani padi yang dibantu oleh kerbau untuk membajak sawah. Berbagai usaha untuk memelihara atau mengembangbiakan ternak disebut sebagai peternakan mencakup dari semua kegiatan perikanan untuk kelompok hewan tertentu dan usaha peternakan ini secara umum masuk pada bagian dari kegiatan pertanian.

Ternak dapat berupa binatang apa pun termasuk serangga dan vertebrata tingkat rendah seperti ikan atau katak. Meskipun demikian, masyarakat biasanya lebih familiar 
pada babi, sapi, kambing, domba, kuda, atau keledai untuk kelompok mamalia domestik dan unggas seperti ayam, angsa, kalkun atau itik untuk kelompok unggas. (https://dosenpertanian.com/pengertianternak/)

\subsection{PAUD (Pendidikan Anak Usia Dini)}

Pendidikan anak usia dini (PAUD) merupakan suatu usaha yang terenncana yang dilakukan kepada anak yang usianya 3-5 tahun dengan pemberian rangsangan pendidikan untuk membantu setiap tumbuh kembangnya baik jasmani maupun rohani, serta mempersiapkan kesiapan mereka untuk menempuh pendidikan lebih lanjut. Pada UUD 45 tepatnya pasal $28 \mathrm{~B}$ ayat 2 menyatakan bahwa "Setiap anak mempunyai hak atas kelangsungan hidup, tumbh dan berkembang serta berhak atas perlindungan dari kekerasan serta diskriminasi."

Selain itu juga pengertian Paud terdapat didalam UU No 23 Tahun 2002 tepatnya pasal 9 ayat 1 mengenai perlindungan anak Kemudian yang terakhir terdapat pada UU No 20 Tahun 2003 mengenai sistem Pendidikan Nasional Bab 1. Lebih spesifik terdapat didalam Pasal 1 butir ke 14. Itulah beberapa landsan dari pengertian Paud yang diambil dari UndangUndang Republik Indonesia. (http://tesispendidikan.com/pengertianpendidikan-anak-usia-dini/)

\section{ANALISIS DAN PERANCANGAN SISTEM}

\subsection{Deskripsi Current System}

Sistem pembelajaran saat ini yang digunakan di TK Dharma Kartika masih menggunakan cara manual yaitu tidak menggunakan media teknologi, hanya menggunakan buku dan alat tulis pada umumnya. Dengan teknlogi yang pada saat ini sedang berkembang pesat, tentu cara belajar seperti ini cukup membosankan untuk anak usia dini. Maka dari itu diperlukan cara dan sebuah aplikasi belajar yang tentunya menggunakan teknologi agar anak tidak cepat bosan untuk belajar.

\subsection{Analisis Masalah}

TK Dharma Kartika memiliki masalah dalam cara mengajar yang manual yang hanya mengandalkan media buku biasa, sehingga guru-guru cukup kesulitan untuk menghadapi anak yang cepat bosan dalam belajar. Maka dari itu diperlukan sebuah metode belajar yang baru dan tidak membosankan yaitu dengan menggunakan bantuan teknologi augmented reality untuk menciptakan aplikasi dan media belajar anak agar anak tidak mudah jenuh.

\subsection{Analisis Pengguna}

1. Murid TK Dharma Kartika dapat menggunakan aplikasi ini.

2. Guru dapat membimbing untuk cara menggunakan aplikasi ini, dari mulai memperlihatkan cara membuka aplikasi sampai aplikasinya berjalan dengan lancar.

\subsection{Use Case}

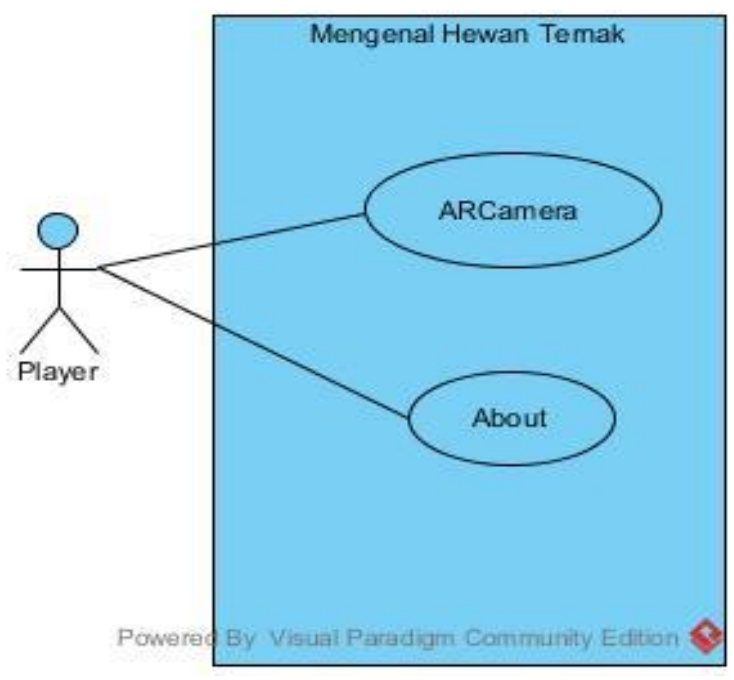

Gambar 1. Diagram Kasus Desain

\subsection{Struktur Navigasi}

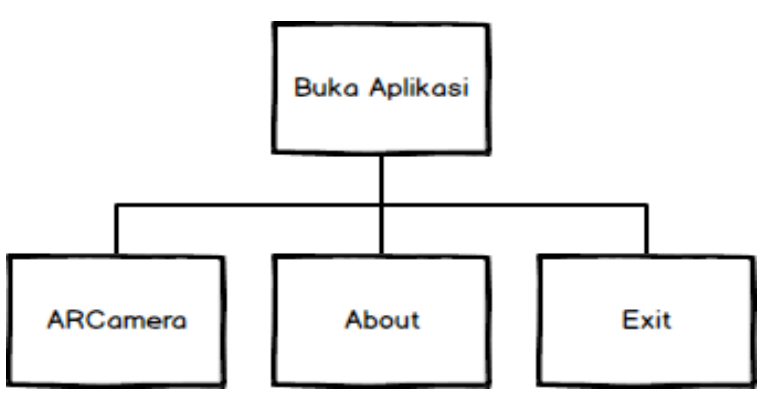

Gambar 2. Struktur Navigasi 


\subsection{Metode Perancangan}

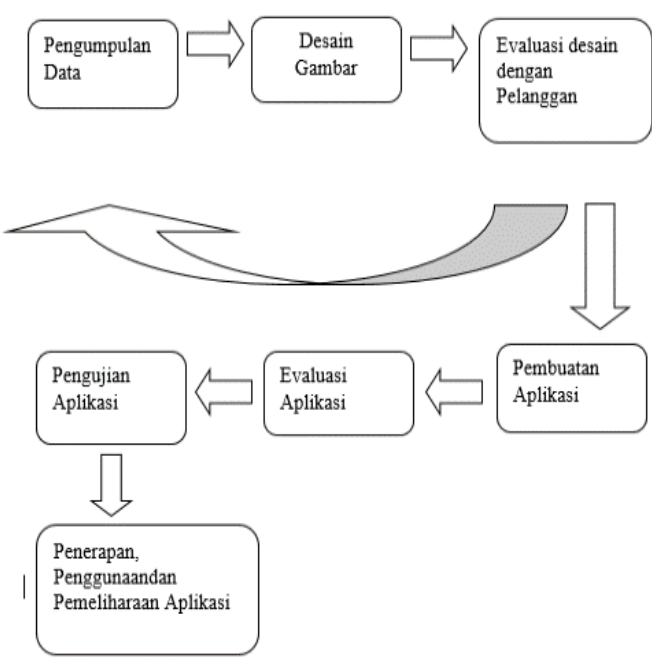

Gambar 3. Desain Aplikasi

\section{IMPLEMENTASI PENGUJIAN SISTEM}

\subsection{Implementasi antar muka}

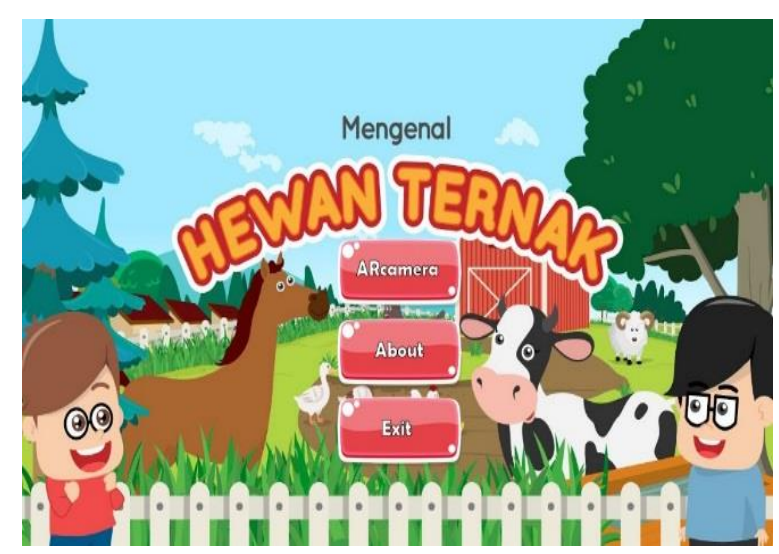

Gambar 4. Tampilan Cover Menu

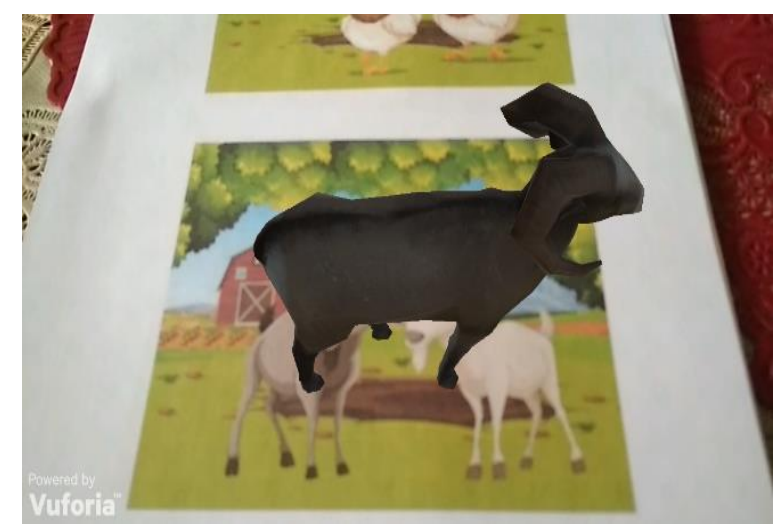

Gambar 5. Tampilan ARCamera

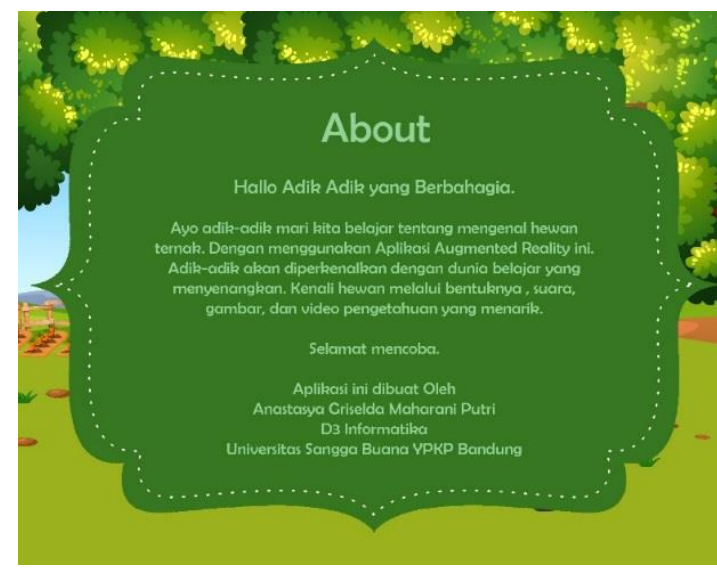

Gambar 6. Tampilan About

\subsection{Pengujian BlackBox}

1. Pengujian ARCamera

Tabel 4.1 ARCamera

\begin{tabular}{|c|c|c|c|}
\hline $\begin{array}{c}\text { Data } \\
\text { masukan }\end{array}$ & Yang diharapkan & Pengamatan & Kesimpulan \\
\hline $\begin{array}{c}\text { Tombol } \\
\text { ARCamera }\end{array}$ & $\begin{array}{c}\text { Menampilkan } \\
\text { Menu ARCamera }\end{array}$ & Sesuai harapan & Valid \\
\hline
\end{tabular}

2. Pengujian About

Tabel 4.2 About

\begin{tabular}{|c|c|c|c|}
\hline $\begin{array}{c}\text { Data } \\
\text { masukan }\end{array}$ & Yang diharapkan & Pengamatan & Kesimpulan \\
\hline $\begin{array}{c}\text { Tombol } \\
\text { About }\end{array}$ & $\begin{array}{c}\text { Menampilkan } \\
\text { Menu } \text { About }\end{array}$ & Sesuai harapan & Valid \\
\hline
\end{tabular}

\section{KESIMPULAN DAN SARAN}

\subsection{Kesimpulan}

Dari hasil pembahasan tentang Pembuatan Aplikasi Augmented Reality Belajar Mengenal Hewan Ternak Berbasis Android Menggunakan Unity TK Dharma Kartika , maka diambil kesimpulan :

1. Aplikasi Augmented Reality ini membantu guru guru dalam proses belajar memperkenalkan hewan ternak.

2. Aplikasi Augmented Reality ini untuk membantu anak dalam belajar mengenal hewan ternak

3. Aplikasi Augmented Reality ini membuat anak tidak cepat bosan dikarenakan cara belajar yang menggunakan teknologi. 


\subsection{Saran}

Saran agar aplikasi ini lebih optimal dan berjalan sesuai dengan yang diharapkan. Ada beberapa saran yang mungkin dapat dipertimbangkan yaitu :

1. Menambahkan objek yang lebih banyak lagi selain hewan ternak

2. Menambahkan fitur interaksi pada objek.

\section{DAFTAR PUSTAKA}

[1] https://dosenpertanian.com/pengertianternak/ (2 Juli 2019, Pukul 19:01 WIB)

[2] https://www.artikelsiana.com/2015/09/p engertian-sistem-informasi-cirifungsi.html\# (2 Juli 2019, Pukul 19:06 WIB)

[3] http://tesispendidikan.com/pengertianpendidikan-anak-usia-dini/ (2 Juli 2019, Pukul 19:11 WIB)

[4] https://www.eurekapendidikan.com/201 5/01/definisi-murid-siswa-dan-peserta- didik.html (2 Juli 2019, Pukul 19:16 WIB)

[5] https://www.gurupendidikan.co.id/8pengertian-guru-menurut-para-ahlipendidikan/ (6 Juli 2019, Pukul 20:01 WIB)

[6] https://eventkampus.com/blog/detail/147 4/apa-itu-unity-3d (6 Juli 2019, Pukul 20:07 WIB)

[7] https://developer.android.com/studio/intr o?hl=ID (6 Juli 2019, Pukul 20:10 WIB)

[8] https://teknojurnal.com/vuforia/ (6 Juli 2019, Pukul 20:15 WIB)

[9] https://jalantikus.com/tips/urutan-versiandroid/ (6 Juli 2019, Pukul 20:20 WIB)

[10] https://www.nesabamedia.com/pengertia n-adobe-photoshop/ (6 Juli 2019, Pukul 20:28 WIB)

[11] http://www.definisipengertian.com/2015/03/definisi-danpengertian-informasi.html (6 Juli 2019, Pukul 20:31 WIB)

[12] https://www.zonareferensi.com/pengerti an-guru/ (6 Juli 2019, Pukul 20:35 WIB) 